\title{
School Starting Age and Academic Performance: An Empirical Study in
} Indonesia

Fawina Aulia Guswandi ${ }^{1}$

Corresponding author. Email: fawinaaulia@gmail.com

Submitted: 2021-10-18 | Accepted: 2021-12-15| Published: December $31^{\text {st }} 2021$

\begin{abstract}
School entry regulations in Indonesia have a specific cutoff date for enrolment and it requires children to start school at the age of seven. In practice, there were schools that allowed children to start elementary school before reaching seven years old. This might create age differences between children in the same grade at school. Some literature has been shown that older students outperform younger students in the school outcomes. For instance, higher education attainment, reduce grade repetition, and excellent academic performances. However, limited evidence exists about the school starting age and academic performances in Indonesia. In order to determine whether the school starting age rule in Indonesia affects children's academic performance, this study utilizes the Indonesian Family Life Survey (IFLS wave) 5 and regression discontinuity design. This study found that older entrance might get lower score compared to the children who start school at early age. Based on the results, entering school earlier might increase the average of total score by 2.687 grade points higher than older entrance.
\end{abstract}

Keywords: school starting age; regression discontinuity design; academic performance.

${ }^{1}$ National Graduate for Policy Studies, Tokyo, Japan. E-mail: fawinaaulia@gmail.com 


\section{Introduction}

Several countries determine the school starting age, the age at which children may officially start the first grade of elementary school, with a specific cutoff date for enrolment. However, the age for children to start elementary school differs between countries, ranging from four to seven years old. In most countries, children start elementary school at the age of six, including in China, Japan, over half of the European countries, and most ASEAN countries. Meanwhile, some countries, including Bulgaria, Estonia, Finland, Latvia, Lithuania, Serbia, and Sweden, set seven years old as the enrolment age. Students in most parts of the United Kingdom (namely, England, Scotland, and Wales) and Australia, Malta, and the Netherlands start school at five (Herbst \& Strawiński, 2016; Stipek, 2002). School starting age in the United States and Switzerland varies by state and canton. Meanwhile, in Indonesia, children enter elementary school if they turn seven years old by the 1st of July, which is slightly late compared to the majority of the ASEAN countries.

The specific cutoff date to enter school may generate differences in the school entrance age amongst students because they have variations in their birthdates. Given this issue, it is challenging to theoretically ascertain the optimal age to start school because children develop in different ways. Therefore, it is important to undertake empirical work to assist policy-making. However, endogeneity might hinder the accurate identification of the impact of school starting age. In this case, endogeneity issues arise from the idea that parents decide whether to send their children to school earlier or postpone it to the next year. Thus, one solution to provide a causal impact of school starting age, the endogeneity issues mentioned must be considered.

Some studies have studied the impact of school starting age on different outcomes such as earnings, educational attainment, criminal involvement, cognitive development, and mental health (Angrist \& Krueger, 1992; Cook \& Kang, 2016; Dee \& Sievertsen, 2018; Dhuey et al., 2019; Smith, 2009). Some researchers argue that schooling at a younger age is beneficial for improving academic performances (Pellizzari \& Billari, 2012) securing higher scores on cognitive tests, and having fewer behavioral problems than older students (Mayer, 1999). Further, Mayer (1999) analyzed children who attained the same amount of schooling and discovered that those who started school earlier had better scores in verbal skills than those who started later. Early entrance also has a positive impact on their lifetime earnings because students are able to enter the labor market earlier (Borghans \& Diris, 2012; Kaila, 2017; Smith, 2009).

On the other hand, child developmentalists derived different insights from the previous arguments. They found that in order to increase their effectiveness in learning, children should start school when they are able to demonstrate maturity both physically and mentally, which typically occurs after the age of four and a half (Bedard \& Dhuey, 2006; Dhuey et al., 2019; Fertig \& Kluve, 2005). Moreover, children who start school at an older age might have better academic outcomes compared to their younger classmates, such as higher test scores and lower probability to repeat grades (Dhuey et al., 2019; Fertig \& Kluve, 2005; Smith, 2009).

In Indonesia, previous studies on school starting age have found that the age of school entry does not have a correlation with students' academic performance (Abdul Hakim, 2018; Rizally, 2014). However, previous findings only covered a limited sample size in specific schools. To address this gap, this research will explore the effect of school starting age with a larger sample size that covers more areas in Indonesia and utilizes different indicators of students' academic performance.

This study aims to evaluate the effect of school starting age, as specified in the current policy, on academic performance. Moreover, this study shows the magnitude of the effect of school starting age on total test scores. Hence, it will provide insights to policymakers in 
enhancing the current policy and achieving the government's goals to improve the quality of human capital.

The remainder of the paper is organized as follows: Section 2 provides the review of the literature on school starting age. Section 3 explains the data and identification strategies adopted to draw conclusions regarding the causal effect of school starting age and academic performance. Section 4 lays out the estimation results and undertakes further discussions on the analysis results. Finally, the last section will offer the conclusions and policy implications.

\section{Literature Review}

\subsection{School Starting Age and Educational Outcomes}

This section briefly discusses the existing literature related to the effect of school starting age on various outcomes. Most of the literature focuses on the outcomes of elementary students and the end of compulsory schooling. This is because the age effect on cognitive ability in the early stages is more permanent, and it may have some effect on students in terms of the adult outcomes such as earnings, educational attainment, and mental health (Angrist \& Krueger, 1992; Cook \& Kang, 2016; Dee \& Sievertsen, 2018; Dhuey et al., 2019; Smith, 2009).

From an economic point of view, the optimal school starting age depends on investment and endowment (Borghans \& Diris, 2012). Such an argument is based on the idea that abilities and skills are cultivated over time. Making investments in the early stages of a child's life cycle is essential for their development and helps ensure that they can accumulate the required skills. Therefore, children who start their investment later might get a lower return (Cunha et al., 2006).

Meanwhile, from the perspective of a child developmentalist, the timing of school entry depends on the child's readiness. Scholars argue that children who are mature enough will gain optimum results in their education. This is because children who are prepared to start school have had extensive experience in the early stages of their development that make them well prepared to handle schooling (Stipek, 2002). Related to this view, there are four aspects that need to be considered for children to start schooling, including physical, psychological, cognitive, and emotional aspects (Adri, 2019). These aspects developed well between the age six until seven years old.

Previous studies on school starting age and educational outcomes highlight two contradictory opinions. Some scholars concluded that children should start schooling at an older age as older children are physically and mentally mature enough to absorb and learn complicated things at school (Bedard \& Dhuey, 2006; Datar, 2006). In line with this view, Bedard \& Dhuey (2006) found that children who are relatively older when they enter school have higher test scores in the fourth and eighth grades across the Organization for Economic Cooperation and Development (OECD) countries. Datar (2006) and McEwan and Shapiro (2008) confirm similar results for the US and Chile. Moreover, Dee and Sievertsen (2018) found that starting school at an older age will reduce inattention/hyperactivity in children and lower their propensity to commit a crime before the age of 18 (Landersø et al., 2017).

In contrast, basic human capital theory suggests that an early start in formal learning will be advantageous for children (Fredriksson \& Öckert, 2005). This is because an early entrance might give opportunities to enter the labor market earlier, helping individuals take returns from human capital investment over a longer term (Angrist \& Krueger, 1992; Becker, 1962; Zhang et al., 2017).

Some studies report a moderate effect of school starting age in the long term. For instance, in Germany, there is no effect of age at school entry on educational outcomes both in terms of schooling degree and probability of having to repeat a grade (Fertig \& Kluve, 
2005) similarly, in Norway, no such effects on education and earnings were noticed (Black et al., 2011). Some studies also indicate that older students perform better in school simply because they are older when they take the test (age-at-test effects) (Elder \& Lubotsky, 2009). Therefore, the effect of school starting age varies across countries with different outcomes.

\subsection{Empirical Studies in Other Countries}

Most countries assign school starting age as six years. For example, in Japan and China, school enrollments can start when children turn six before the cutoff date, which is April 1st and August 31st, respectively. Both countries require nine years of compulsory schooling. Empirical research in Japan describes that children who start school at an older age obtain higher test scores among both sexes and more education years than their younger peers (Kawaguchi, 2011). This better academic performance translates into higher annual earnings among males (Kawaguchi, 2006; Zhang et al., 2017). Additionally, an empirical study in China explored the effect of school starting age on cognitive test scores and found that a one-year delay in school entry may decrease the test scores; this negative effect becomes larger for children from rural schools (Zhang et al., 2017).

Meanwhile, compared to other countries, school entry in the UK occurs earlier, at five years old. This age was set to ensure child protection. For instance, lowering the school starting age might protect children from exploitation at home and dangerous conditions on the streets (Sharp, 2002). Another reason is that setting an early age might enable students to leave school earlier, allowing them to enter the workforce earlier (Sharp, 2002, p.3).

The school entrance age in Finland is seven years, which is fairly late compared to most EU countries. This is an attempt to improve the child's development process. Postponing early schooling might give children more time to play, which is beneficial for their development, and if formal schooling starts earlier, it will disturb the development process (Kaila, 2017).

\subsection{School Starting Age and Education System in Indonesia}

The Indonesian educational system is composed of four stages: preschool, elementary school, junior high school, and senior high school. Children usually enroll in preschool or kindergarten at the ages of four or five years. It is optional for them to enroll in preschool before continuing to elementary school, and many of these schools are privately owned. The 2003 Indonesian Education Act provides the right to receive nine years of compulsory school from elementary school until junior high school. According to the regulations of the Ministry of Education and Culture concerning the admission of new students in pre-primary, primary, and secondary schools, elementary schools are obliged to accept students at age seven with a minimum age of six years on July 1 . An exception to this age requirement is being at least five years and six months on July 1 . The exception is only for pupils who demonstrate high ability and intelligence and/or special talent and psychical readiness as evidenced by a written recommendation from a professional psychologist.

There are limited studies that discuss the effect of school starting age on academic performance in Indonesia. One example is Wicaksono and Witoelar (2019), who found that starting schooling at an older age is negatively associated with school continuation from the primary to secondary levels. Another study in an elementary school in Padang, Indonesia tested whether school starting age has a correlation with learning achievement (Rizally, 2014) and found no significant correlation between school starting age and academic achievement. However, the methodology in this study was limited to a correlation between variables and only covered a small sample. 


\section{Data and Methods}

\subsection{Data}

To study how school starting age affects the educational outcome of pupils in Indonesia, this study utilizes the fifth wave of the longitudinal Indonesian Family Life Survey (IFLS) conducted in 2014 by the RAND Corporation (Strauss et al., 2016). IFLS covers over 30,000 respondents from 13 of the 34 provinces in Indonesia, which $83 \%$ of the Indonesian population inhabits. The first wave of the survey was conducted in 1993 and followed up in 1997, 2003, and 2007 for the second, third, and fourth waves, respectively. The data gives comprehensive information at the individual, household, and community levels covering issues from socio-economic conditions and educational background. The IFLS data sets provide individual educational background information including the National Examination Scores for each subject (Bahasa Indonesia, English, and Mathematics), parents' income, class size, school distance, and kindergarten participation. The survey provides key information about the individual's date of birth as well as the highest grade completed.

This study examines the effect of school starting age on academic performance in elementary school by using the national examination scores which consist of Bahasa Indonesia, English, and Mathematics scores. Additionally, high elementary school scores serve as a milestone for students, boosting their desire to continue their studies. These test scores determined the students' next schooling and are further significant as continuing their studies at the best school will provide them a better academic environment and network.

We utilize the age of entry to school as an assignment variable, which measures the distance of the school starting age from the cutoff point. In this paper, to calculate school starting age, we follow previous studies (Elder \& Lubotsky, 2009; Zhang et al., 2017) by using detailed information on grade repetition. The actual school starting age (SSA) can be defined as SSA $=($ year of enrollment - year of birth $)+(7-$ month of birth $) / 12$.

The scale of the test score for each subject range from 0 to 10 . Therefore, if a student obtains an excellent score for all subjects, they will get 30 as the highest score. As the outcome variable, the test score will vary from o to 30. Subsequently, to control the validity of the regression model, we constructed control variables that include school administration, school distance, grade repetition, parents' income, gender, and kindergarten participation. There are a few problems with the data that are mostly related to missing variables. In the overall survey results, some observations may have missing values. Then, we drop the observations that have missing values in the sample of quesionaire and combine all variables that needed as a data set.

\subsection{Methodology}

This study uses regression discontinuity design (RDD) to estimate the effect of school starting age on academic achievement. An RDD is a way of undertaking causal inference, and it is able to identify a treatment effect by comparing the outcomes near the threshold (Lee \& Lemieux, 2010). Thus, it can provide robust results and convincing estimates of causal impacts under reasonably weak conditions or minimal assumptions (Angrist \& Krueger, 1992). An RDD is appropriate where a treatment or intervention is given to individuals for whom some measured characteristic lies on one side of the cutoff and when individuals cannot perfectly manipulate the character (Lee \& Lemieux, 2010; Smith, 2009).

To examine whether the school starting age affects educational outcome, I estimated the following regression:

$$
Y_{i}=\beta_{0}+\beta_{1} S S A_{i}+\beta_{2} D_{i}+\left[X_{i}\right]+e_{i}
$$


where $\boldsymbol{Y}_{\boldsymbol{i}}$ denotes the outcome of student i, which in this paper, is the total score from the national examination. $\boldsymbol{S S} \boldsymbol{A}_{\boldsymbol{i}}$ is the school starting age, which is calculated as the child's age on July 1 in the school year that they entered primary school. $\boldsymbol{\beta}_{\mathbf{2}}$ is the causal interest and school starting age is considered an assignment or running variable. RDD captures the causal effects by distinguishing the nonlinear and discontinuous function, $1\left(x_{i} \geq x_{0}\right)$. $\left[\boldsymbol{X}_{\boldsymbol{i}}\right]$ represents control variables that include school administration, school distance, grade repetition, parents' income, gender, and kindergarten attendance. $\boldsymbol{e}_{\boldsymbol{i}}$ is the error term, and $x_{0}$ is a known threshold or cutoff. Regression discontinuity compares the SSA of students with age just before and after the school entry cutoff to identify the treatment effect at the threshold and examine the estimated local average treatment effects (LATE) for a subgroup of observations near the cutoff.

$$
\boldsymbol{D}_{\boldsymbol{i}}= \begin{cases}1, & \text { if } x \geq x_{0} \\ 0, & \text { if } x<x_{0}\end{cases}
$$

The first idea of RDD is to examine some individuals who are categorized to be treated and untreated by a policy (Kaila, 2017). Moreover, the cutoff date for determining school starting age is set as July 1 , as children start school in Indonesia if they reach the age of seven by July 1 . Thus, children born before the cutoff start school at an early age whereas children born after the cutoff will enter school at an older age. To a certain extent, birthdays should be randomly determined, which implies that people born close to the threshold are randomly assigned to start school at a different age, compared to those on the other side of the threshold. In this case, children's birthday is already determined randomly because parents cannot decide the exact time to give birth to their child. Therefore, there is no manipulation of the birthday as the proxy of school starting age. If the assignment is approximately random, the individuals whose birthdays fall just before the cutoff provide a good counterfactual to those whose birthdates fall just after the cutoff. By comparing these groups, we can study the causal effects of the discontinuous "jump" in school starting age on academic performance.

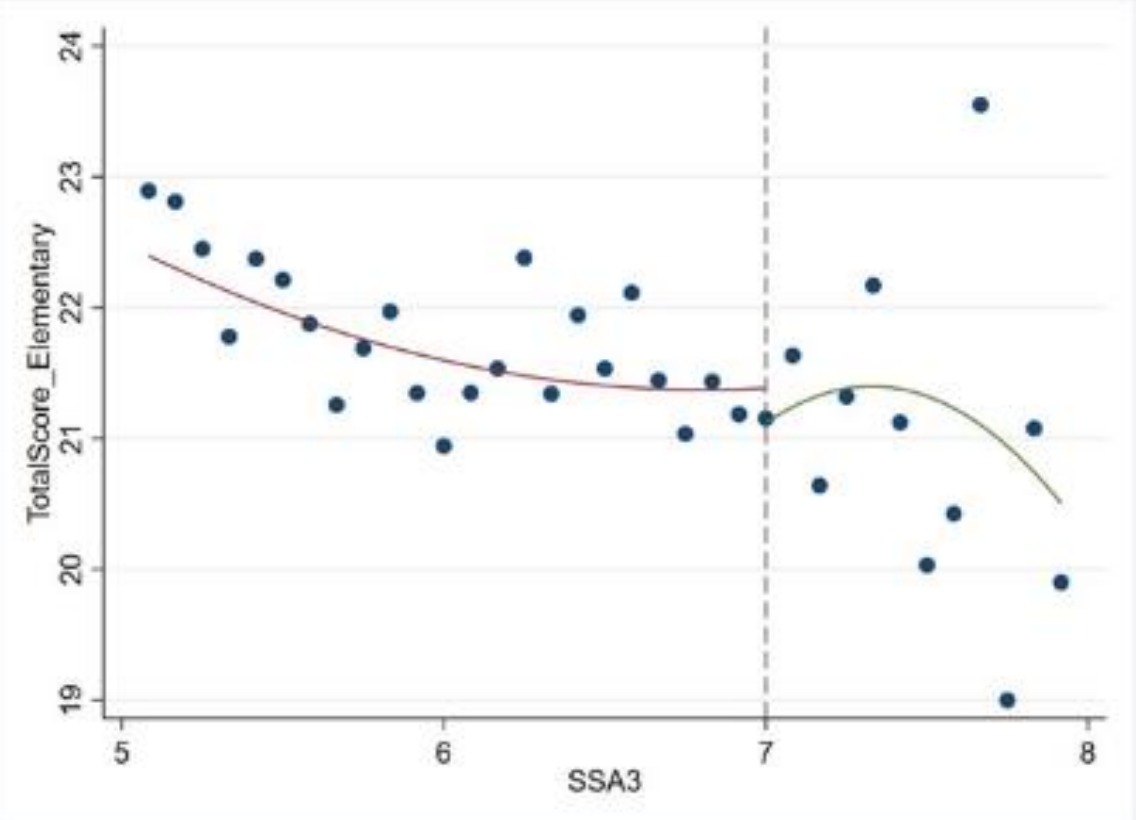

Figure 1. Discontinuity in the Assignment Variable 
Figure 1 depicts the discontinuity in the school starting age as an assignment variable. In this case, there is a discontinuity drop between the school starting age and the children's test scores, in which children who enter school at an earlier age have a higher score compared to the older entrants. A regression model can be used to estimate the effect of the discontinuous drop. First, I use a simple regression analysis by employing the ordinary least square (OLS) estimation to motivate the use of RDD. OLS estimation obtains the correlation between SSA and test scores with the following equation:

$$
\boldsymbol{Y}_{i}=\alpha+\alpha_{1} S S A_{i}+\alpha_{2} X_{i}+e_{i}
$$

where $\boldsymbol{Y}_{\boldsymbol{i}}$ denotes the educational outcome of student $i, \boldsymbol{S} \boldsymbol{S} \boldsymbol{A}_{\boldsymbol{i}}$ is the binary variable which explains whether the student is categorized as an older or younger entrant. A value of 1 is assigned if the students start school at an early age and o if otherwise. $\boldsymbol{X}_{\boldsymbol{i}}$ contains the control variables and $e_{i}$ is the error term. The regression result is presented in Table 1 and shows that there is a negative correlation between the school starting age and total test score. However, the estimation is probably biased since there are other variables that may be correlated with school starting age such as learning disabilities; hence, we cannot take the estimation as causal inference.

To estimate the effect of a discontinuous "jump" in school starting age on total test score, we use Equation 1, where the main parameter is $\boldsymbol{\beta}_{2}$, which captures the causal effect of the school starting age. One important condition from RDD to offer causal inference is the absence of manipulation in the running variable (Lee \& Lemieux, 2010). In this study, we assume that parents are unable to exactly determine their children's birthday, so that we can hold the assumption of no manipulation. Consequently, the treatment is approximately locally randomized and individuals who are assigned just before and after the cutoff are on a similar averages, but would be exposed to different treatment (Kaila, 2017).

\section{Results, Analysis, and Discussions}

\subsection{Descriptive Statistics}

Table 1 depicts the statistical summary of each variable. The average total score of the national examination is 21.52, with the average scores for each subject being 7.27 (Bahasa), 6.85 (English), and 6.85 (Mathematics). The score for each subject varies from 0 to 10 , and children will get the highest score of 30 points if they get perfect scores of 10 points in each subject.

In this study, the number of females and males in the sample is almost equal and $15.11 \%$ of the total sample experienced grade repetition in elementary school. In general, school classification in Indonesia can be divided into several categories: public school, private school, religious school, and non-religious school. The data captures that most of the schools in the sample are managed by the government, and most of them are non-religious schools $(84.77 \%)$. Meanwhile, the number of private schools in Indonesia is not substantial compared to public schools, both for private non-religious and private religious schools.

Additionally, the data reveals that the average travel time to go to school is around 14 minutes. This result implies that the distance to school is not too far. The close location of the school might also be beneficial for students as they do not have to spend much time traveling. However, children's participation in kindergarten in Indonesia is low, as shown in Table 1, with the participation rate being just $25.8 \%$. One possible cause is that the government only mandates nine years of compulsory schooling and does not prioritize early childhood education. It can perhaps also be attributed to the cost of pre-school education in Indonesia, which is relatively too high for most parents, especially for lower income family. 
Fawina Aulia Guswandi

Table 1. Summary Statistics

\begin{tabular}{|c|c|c|c|c|}
\hline Variable & Mean & Std. Dev. & Min & Max \\
\hline Total Score & 21.52949 & 4.430758 & 2.25 & 30 \\
\hline - Score Bahasa & 7.273451 & 1.206989 & 0.75 & 10 \\
\hline - Score English & 6.849066 & 1.489648 & 0.8 & 10 \\
\hline - Score Mathematics & 6.855506 & 1.664571 & 0.75 & 10 \\
\hline Grade Repetition & 0.151168 & 0.3582528 & $\mathrm{O}$ & 1 \\
\hline Parent's Income (1000 IDR) & 25,200 & 49,100 & 1000 & $1,000,000$ \\
\hline School Administration & 1.372937 & 0.9576038 & 1 & 7 \\
\hline - Public non-religious & 0.8477448 & 0.3593076 & $\mathrm{O}$ & 1 \\
\hline - Public religious & 0.0356436 & 0.1854202 & $\mathrm{O}$ & 1 \\
\hline - Private non-religious & 0.0253025 & 0.1570597 & $\mathrm{O}$ & 1 \\
\hline - Private Islam & 0.0822882 & 0.2748336 & $\mathrm{O}$ & 1 \\
\hline - Private Catholic & 0.0055006 & 0.0739696 & $\mathrm{O}$ & 1 \\
\hline - Private Christian & 0.0033003 & 0.0573599 & $\mathrm{O}$ & 1 \\
\hline - Private Buddhist & 0.00022 & 0.0148331 & $\mathrm{O}$ & 1 \\
\hline Travel Time & 14.81728 & 15.31798 & 1 & 120 \\
\hline Gender (1=Male) & 0.4826165 & 0.4997046 & $\mathrm{O}$ & 1 \\
\hline Kindergarten $(1=$ Yes $)$ & 0.2580702 & 0.4375792 & $\mathrm{O}$ & 1 \\
\hline
\end{tabular}

\subsection{School Starting Age Distribution in Indonesia}

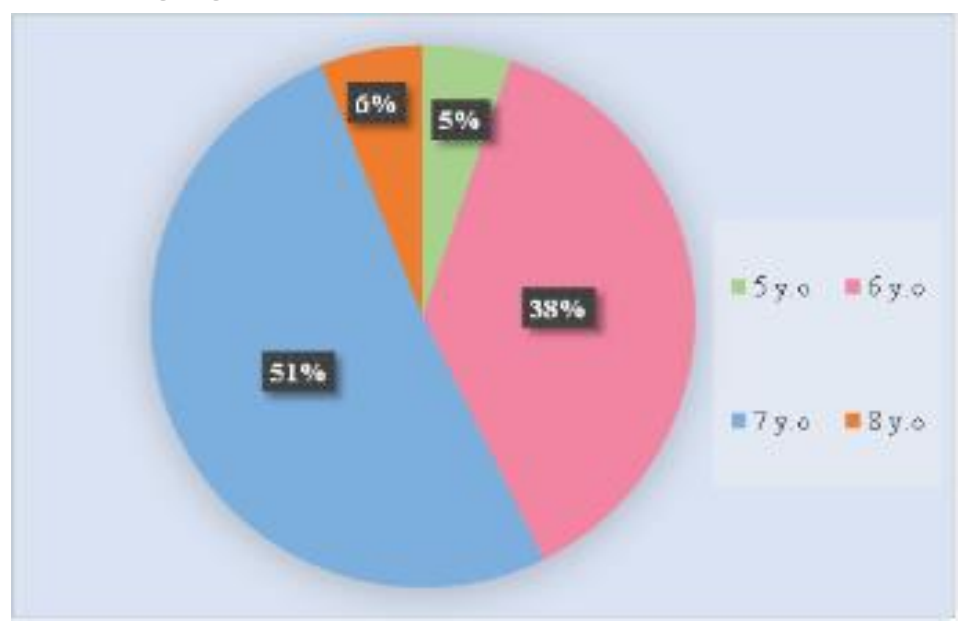

Figure 2. Distribution of School Entry Age 
Figure 2 captures the distribution of school entry age in Indonesia, in which children in Indonesia mainly start school at the ages of seven and six years $(51 \%$ and $38 \%$, respectively). Compared to these numbers, only six percent enroll at the age of eight and only a small number of children start school earlier than the age of five. In order to capture spatial difference areas, this study tried to divide the distribution of school starting age into Java and non-Java areas. Java consists of the Java and Bali areas, the regions that Indonesia's development is most centralized to; meanwhile, non-Java comprises of the other areas in Indonesia, including some areas in Sumatra, Kalimantan, and Sulawesi

In Table 2 , we can see the distribution of school starting age by area and gender. In general, the same pattern occurs both in Java and non-Java areas, in which most children start school at the ages of six or seven. However, the proportion entering school at age six in the non-Java areas is greater than in Java by $2.98 \%$. In the Java areas, the proportion of school-enrolling children at the ages of six and seven are $51.53 \%$ and $36.73 \%$, respectively, while in the non-Java areas, entrances at ages six and seven stand at $54.51 \%$ and $37.04 \%$, respectively. Moreover, in both areas, children are more likely to start school at the early age of five. There is only a small number of children who enter at a later age.

Table 2. School Starting Age Distribution by Area and Gender

\begin{tabular}{|c|c|c|c|c|c|c|}
\hline & \multicolumn{3}{|l|}{ Java } & \multicolumn{3}{|l|}{ Non-Java } \\
\hline $\begin{array}{l}\text { School } \\
\text { Entry } \\
\text { Age }\end{array}$ & Quantity & $\begin{array}{l}\text { \% Students } \\
\text { for each } \\
\text { group by } \\
\text { gender }\end{array}$ & $\begin{array}{l}\text { \% } \\
\text { Students } \\
\text { by age } \\
\text { group }\end{array}$ & Quantity & $\begin{array}{l}\text { \% Students } \\
\text { for each } \\
\text { group by } \\
\text { gender }\end{array}$ & $\begin{array}{c}\% \\
\text { Students } \\
\text { by age } \\
\text { group }\end{array}$ \\
\hline \multicolumn{7}{|l|}{ Age 5} \\
\hline - Girl & 26 & $65.00 \%$ & \multirow{2}{*}{$10.20 \%$} & 23 & $63.89 \%$ & \multirow{2}{*}{$6.91 \%$} \\
\hline - Boy & 14 & $35.00 \%$ & & 13 & $36.11 \%$ & \\
\hline \multicolumn{7}{|l|}{ Age 6} \\
\hline - Girl & 96 & $47.52 \%$ & \multirow{2}{*}{$51.53 \%$} & 149 & $52.46 \%$ & \multirow{2}{*}{$54.51 \%$} \\
\hline - Boy & 106 & $52.48 \%$ & & 135 & $50.00 \%$ & \\
\hline \multicolumn{7}{|l|}{ Age 7} \\
\hline - Girl & 69 & $47.92 \%$ & \multirow{2}{*}{$36.73 \%$} & 86 & $44.56 \%$ & \multirow{2}{*}{$37.04 \%$} \\
\hline - Boy & 75 & $52.08 \%$ & & 107 & $55.44 \%$ & \\
\hline \multicolumn{7}{|l|}{ Age 8} \\
\hline - Girl & 2 & $33.33 \%$ & \multirow{2}{*}{$1.53 \%$} & 4 & $50.00 \%$ & \multirow{2}{*}{$1.54 \%$} \\
\hline - Boy & 4 & $66.67 \%$ & & 4 & $50.00 \%$ & \\
\hline Total & 392 & & $100.00 \%$ & 521 & & $100.00 \%$ \\
\hline
\end{tabular}

Even though Java and non-Java share the same patterns for school starting age, several differences exist in terms of gender. First, girls dominated mostly in the earlier entrances, accounting for $65 \%$ in Java and $63.89 \%$ in the non-Java area. Also, two-thirds of late starters in Java were predominantly boys, while in the non-Java areas, both sexes shared 
the same numbers. Second, Table 2 shows that the proportion of girls who take the early entrance was greater than boys by $30 \%$ in the Java area and by $27.78 \%$ in the non-Java area. In the age six category, which is when the majority of children start school, girls compose a greater percentage in the non-Java areas $(52.46 \%)$ compared to Java, while the percentage of boys in Java is $4.96 \%$ more as compared to girls.

Therefore, according to Figure 2 and Table 2 , the majority of children start school at the age of six. This condition applies to the Java and non-Java areas, as well as for both genders.

\subsection{School Starting Age and Academic Outcomes}

Children in the sample took the national examination that consists of three sections: Bahasa Indonesia, English, and Mathematics. The government designed the exam specifically for final grade assessment in elementary schools, and it is conducted simultaneously throughout Indonesia. It is not the standard final grade assessment that is usually used in schools. The minimum and maximum scores for each subject were 0 and 10 . Thus, children will get a maximum of 30 points for their total score if they get perfect scores for each subject.

Figure 3 shows the comparison of the elementary school national examination scores, including Total Score, and individual Bahasa, English, and Mathematics scores, for both male and female students, based on their school starting age. Students who entered elementary school at or between the ages of five and seven had relatively similar average scores (of 21 ) for both male and female students. However, a closer look at the diagram shows that there are several different total score patterns in each age group and for each gender. For students who enrolled at five years of age, female students could achieve a perfect total score of 30 , while male students could only achieve a maximum total score of around 27 . However, there were more male students who achieved higher than the average score compared to female students.

Conversely, in the six-years age group, the maximum score for male students is higher than that of female students, while the minimum scores of both genders are relatively the same at around 13. The diagram also reveals that there is a small decrease in the scores of female students who enrolled at the age of six years, compared to those who enrolled at the age of five. Contrarily, male students in this age group had a higher score compared to the younger age group. Additionally, students who enrolled at the age of seven years did not achieve higher scores compared to those who enrolled at the age of six, among both females and males. Moreover, their minimum scores were also lower. The scores of the females were nearly normally distributed. On the other hand, there are more male students who had lower than average scores.

Finally, the oldest age group, eight years old, shows a clear distinction in the scores trend. Female students who enrolled at this age had a higher average score compared to the younger female students, but the male students in this age group show the least score on average. 
Total Score for Girls

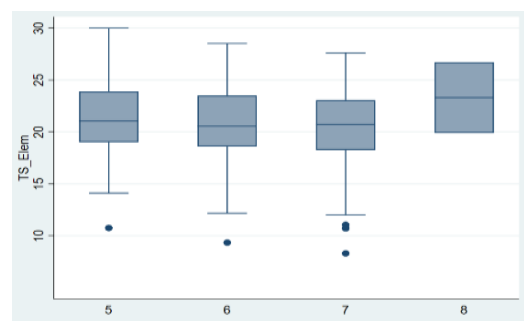

Bahasa Score for Girls

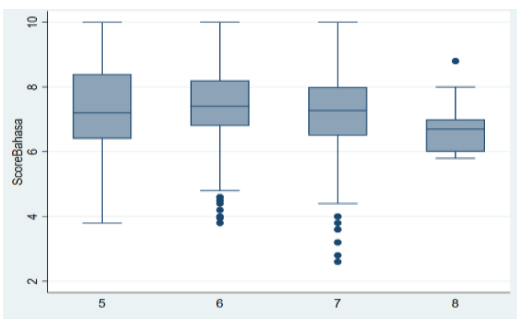

English Score for Girls

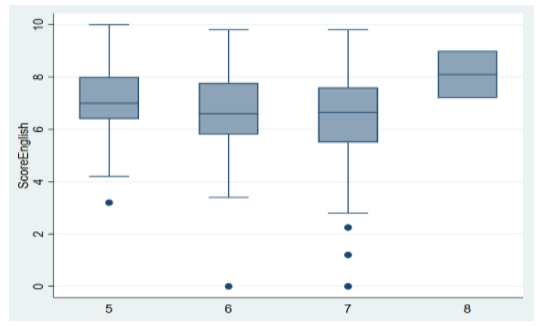

Mathematics Score for Girls

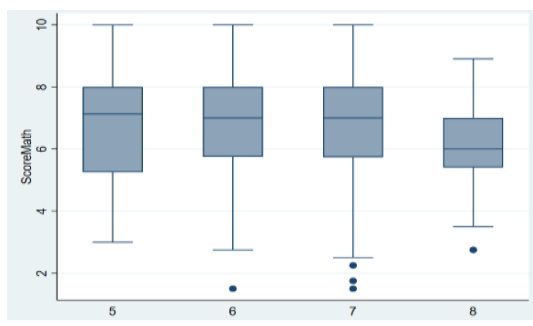

Total Score for Boys

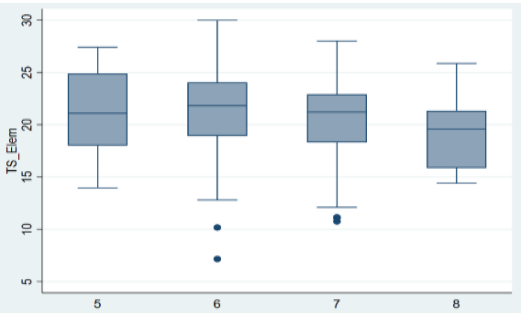

Bahasa Score for Boys

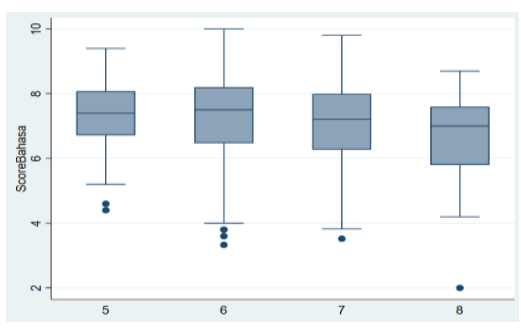

English Score for Boys

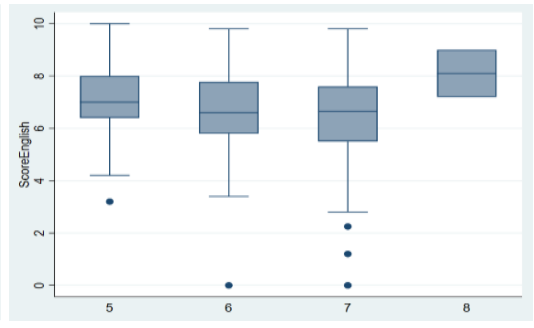

Mathematics Score for Boys

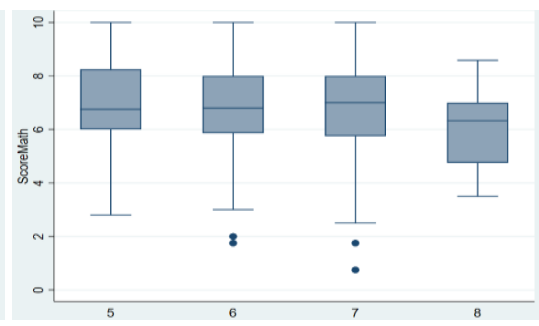

Figure 3. Gender Differences in Test Scores

There are some differences in the Bahasa scores with respect to gender differences (see Figure 3). First, female students who enrolled at the ages of five to seven had the same maximum score of 10 , while those who enrolled later at the age of eight years only had a maximum score of 8 . Furthermore, female students who enrolled at the age of six years showed the highest average score of all age groups. Compared to the age groups of five and seven, female students in the six-years age group had their highest minimum score at around 5. On the other hand, female students who enrolled at eight years old had their highest minimum score at slightly below 6 , even though their average score was the lowest among all the other age groups.

The pattern of the Bahasa scores for each age group is different for the male students. Only male students in the seven-years age group achieved the perfect score of 10 . Their 
average score was also the highest among other age groups, at around 7.5. However, there were several outliers in this age group who had scores lower than the other groups. The score distribution of the seven-years age group is slightly different from that of the six-years age group, and their minimum and average scores were lower. Male students in the fiveyears age group had the shortest box plot, indicating that in this age group for the Bahasa score distribution, most students achieved scores that were close to their average, at around 7.5. Similar to the female students, male students who enrolled at the age of eight years had the lowest average score compared to other age groups.

In terms of English scores, Figure 3 shows that for female students, those who enrolled at eight years old had the highest average score and the best score distribution among the age groups. For students in the age groups of five years to seven years, the older they enter elementary school, the lower their average and minimum scores. Female students in the five-years age group had the highest score of 10 , an average score of around 7 , and a minimum score of 6.2. The maximum scores of age groups six years and seven years were both marginally below 10; however, the minimum score of the students in the seven-years age group was lower than that of the six-years age group. Moreover, there were more female students who achieved English scores above the average in the six-years age group, compared to those in the seven-years age group.

The average scores of the male students were almost similar for all age groups, at around seven. Male students in both the age groups of six years and seven years could achieve a maximum score of 10 , but the average and minimum scores of those in the six years age group were higher compared to those in the seven years age group. The oldest age group, at eight years old, showed better distribution compared to the other groups. Their minimum scores were the highest, at around 4, and they had the most students who scored above average.

It can be seen in Figure 3 that both female and male students had a similar trend in mathematics scores: those who enrolled at the earlier age at five to seven years old could achieve a perfect score of 10 , while those who enrolled at a later age of eight could not achieve a perfect score (around 9 for female students and around 8.5 for male students). Nevertheless, the average scores of age groups five to seven were higher for female students than for male students. Female students in these age groups had a relatively similar average score at around 7 . On the other hand, male students in these age groups scored slightly lower at around 6.5.

Comparing the six- and seven-years age groups, the mathematics score for the former is relatively better than the latter for both genders. While both age groups had the same maximum score, the minimum score of the six-years age group was higher than the sevensyears age group, both for female and male students. Furthermore, for male students, there were more students who had a higher than the average score in the six-years age group.

Furthermore, girls dominated mostly in the earlier entrance, while late starters were predominantly composed of boys. However, children were more likely to enroll earlier rather than being late entrants. Before they start primary school, children should demonstrate good signs of school readiness. The indicators of school readiness consist of five development areas: physical health, motoric development, socio-emotional development, linguistic development, and cognitive development (Deliviana, 2017). Children need to perform well in these indicators of school readiness so that they are able to adapt to the school environment and participate in learning activities. 

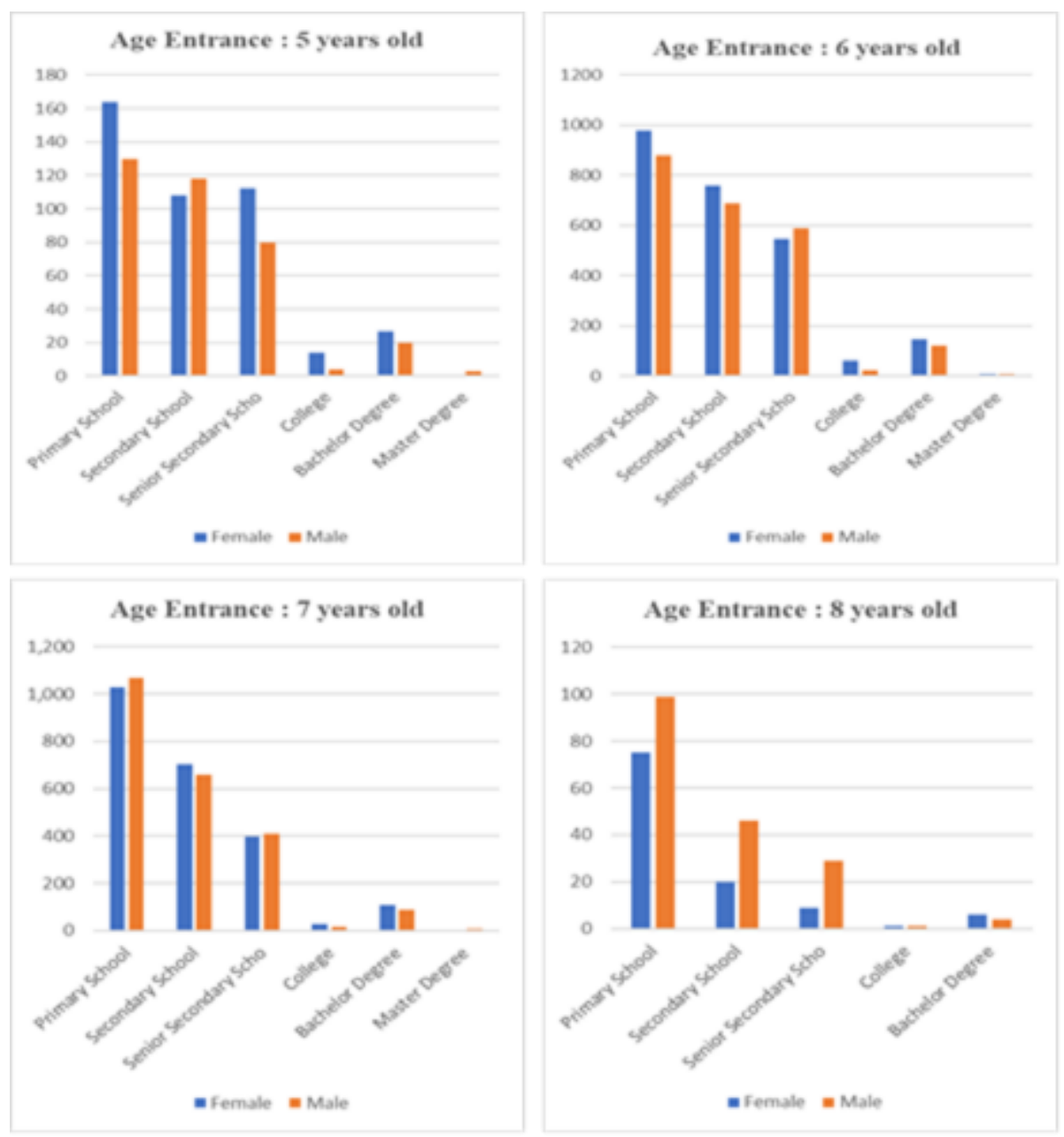

Figure 4. School Starting Age and Educational Attainment

Figure 4 depicts the relationship between school starting age and educational attainment for both genders at every age of entrance. In the earlier age entrance at five years old, most children, both girls and boys, finished their school at the primary school level, but the number of girls who finished school at the primary level outweighs the number of boys who did the same. For junior and senior secondary school, the female entrants shared the same pattern at around 100 and 130 people. Meanwhile, the number of boys at these levels decreased significantly from 118 to 80 persons. In terms of higher education, only a small number of children finished college and attained a master's degree. Moreover, a significant drop is being observed in terms of the higher education attainment of six-year-old entrants. Only a small number of students are finishing their bachelor's degrees.

Children who start school at the age of seven are more likely to have educational attainment only at the primary level, and it continues to decrease significantly in junior and senior secondary school. In terms of gender, male students are a greater number in primary and senior secondary school, while female students are more likely to finish their education at junior secondary and bachelor's levels. Interestingly, for eight-year-old starters, male students dominated in all levels of education except for bachelor's degrees, and they shared significant differences with female starters. For instance, there are 99 male and 75 female students who enter school at the age of eight but limited their education to the primary level. 
Additionally, children who start school at the age of eight mostly finish their education with a bachelor's degree. They do not continue their study until master's degree. Finally, most students in every age group are more likely to stop their education at the primary school level, and there are a limited number of students who continue their studies until higher education, especially for a master's degree.

\subsection{The effects of School Starting Age on Academic Performance}

The graphical results in Figure 1 reveal that the age entrance rule creates a discontinuity drop around the threshold. To clarify the results and answer the question of how school entrance age can significantly impact elementary test scores, this study provides the OLS estimations and RDD. For the first estimations technique, this study estimates the correlation between the school entrance age and test scores through the simple OLS procedure. We provide the OLS estimation using Equation 2 with and without covariates. The covariates contain six control variables including grade repetition, parents' income, school administration, travel time to school, gender, and kindergarten participation (see Table 2).

Table 3. Regression Results

\begin{tabular}{|c|c|c|c|c|}
\hline \multirow{2}{*}{ Variables } & (1) & (2) & (3) & $(4)$ \\
\hline & OLS & $\begin{array}{l}\text { OLS with } \\
\text { Covariates }\end{array}$ & RDD & $\begin{array}{l}\text { RDD with } \\
\text { Covariates }\end{array}$ \\
\hline \multirow[t]{2}{*}{ School Starting Age } & $-0.382^{*} *$ & -0.432 & & \\
\hline & $(0.190)$ & $(0.359)$ & & \\
\hline \multirow[t]{2}{*}{ Grade Repetition } & & -0.584 & & \\
\hline & & $(0.474)$ & & \\
\hline \multirow[t]{2}{*}{ Parents' Income } & & 0.060 & & \\
\hline & & $(0.122)$ & & \\
\hline \multirow[t]{2}{*}{ School Administration } & & -0.106 & & \\
\hline & & $(0.136)$ & & \\
\hline \multirow[t]{2}{*}{ Travel time to school } & & -0.016 & & \\
\hline & & $(0.014)$ & & \\
\hline \multirow[t]{2}{*}{ Gender } & & 0.256 & & \\
\hline & & $(0.282)$ & & \\
\hline \multirow[t]{2}{*}{ Kindergarten } & & $1.481^{* * * *}$ & & \\
\hline & & $(0.301)$ & & \\
\hline \multirow[t]{2}{*}{ Conventional } & & & -0.094 & $-2.633 * * *$ \\
\hline & & & $(0.259)$ & $(0.095)$ \\
\hline Bias corrected & & & -0.148 & $-2.687 * * *$ \\
\hline
\end{tabular}


Fawina Aulia Guswandi

\begin{tabular}{|l|r|r|r|r|}
\hline \multirow{2}{*}{ Variables } & $(1)$ & \multicolumn{1}{c|}{$(2)$} & \multicolumn{1}{c|}{$(3)$} & \multicolumn{1}{c|}{$(4)$} \\
\cline { 2 - 5 } & OLS & $\begin{array}{c}\text { OLS with } \\
\text { Covariates }\end{array}$ & \multicolumn{1}{c|}{ RDD } & $\begin{array}{r}\text { RDD with } \\
\text { Covariates }\end{array}$ \\
\hline & & & $(0.259)$ & $(0.095)$ \\
\hline Robust & & & -0.148 & -2.687 \\
\hline & & & $(0.309)$ & $(2.089)$ \\
\hline constant & $21.592^{* * * *}$ & $19.891^{* * *}$ & & \\
\hline & $(0.086)$ & $(1.964)$ & & 970 \\
\hline $\mathrm{N}$ & 3341 & 981 & 3341 & \\
\hline
\end{tabular}

Standard errors in parentheses $* \mathrm{p}<.1, * * \mathrm{p}<.05, * * * \mathrm{p}<.01$

Columns 1 and 2 of Table 3 show the results of the OLS estimations. First, the OLS estimation without covariates found that earlier enrollment in elementary school exerts a negative and significant impact on elementary test scores. Younger students are more likely to get a higher test score with 0.382 more points compared to older students. This study also examined a simple OLS regression with covariates which was expected to reflect the composite effect of age on the test scores, including the influence of the control variables. As it turns out, the result is insignificant for all variables except kindergarten attendance. We found that joining kindergarten may have positive and significant correlations with the test scores. On average, children who enroll in kindergarten have 1.481 points higher than those who do not. This shows that extensive experience in early childhood education may offer beneficial outcomes in children's academics. Joining kindergarten before starting elementary school might support the readiness of children to start schooling, as they are more comfortable and better prepared to handle school than classmates who have little experience in early education (Kartal et al., 2016; Stipek, 2002).

The second estimations technique is expected to explore the causal effects of school starting age on academic performance by using RDD. The estimated results of the RD design are presented in columns 3 and 4 of Table 3. When excluding the covariates, the RDD estimates the insignificant and negative results with respect to the total scores of the elementary exam. The results for the RD design without the covariates do not provide significant results. Later, this study uses covariates to increase the precision of the treatment effect estimation and to eliminate bias, as well as to reduce the variance (Frölich \& Huber, 2017). When controlling the covariates, the RDD specifications show larger size estimates of SSA, and the results found that students whose birthdates fall before the cutoff have, on average, 2.687 grade points higher than the scores of students with birthdays falling just after the cutoff.

Interestingly, we found a consistent negative effect of school entrance age on test scores in both the estimation techniques. This indicates that children who enroll in elementary school at an early age might have higher test scores compared to older entrants. A discontinuity drops around the threshold may be attributed to the causal effects of school starting age on academic performance.

Moreover, early entrance (entry age below seven) is not associated with the worst outcomes. This could be because children may attain benefits from early exposure to education. The opportunity cost of early enrollment is bigger compared to postponing enrollment. This is because when parents make the decision to postpone the start of elementary school, children are more likely to stay at home. However, for wealthy families, 
when parents hold back their children from entering school, they are more likely to invest their children in one year of kindergarten or preschool.

Meanwhile, for lower socio-economic status groups, parents are more likely to send their children to school early. This is because they cannot provide their children with proper early childhood education. Therefore, the opportunity costs for sending their children to school are higher than postponing enrollment. Supporting this idea, Sharp (2002) claimed that early enrollment might protect children from exploitation at home as well as from unhealthy conditions on the streets.

Furthermore, the estimation above implies that the school starting age has a significant effect on academic performance. Children's early enrollment in elementary school does not turn into a negative condition. On the other hand, early entrants are able to demonstrate a good result in test scores. Therefore, by considering some conditions with respect to school entrance age, it would be better for children to attend school at an early age, rather than postponing their enrollment to the age of seven years.

\section{Conclussion and Recommendation}

This study evaluates the effect of school starting age on students' academic performance in elementary school. The main conclusion of this study is that the age of entry into schooling might have a significant effect on the academic performance of elementary school students. Moreover, our analysis includes some aspects related to test scores and gender.

First, in general, early entrance students demonstrate higher scores in almost every subject. Also, entering school earlier might increase the total score by 2.687 grade points. To support this idea, this study tried to lower the school starting age to six years and found that entering school at a lower age may increase the average test score by 1.624 points. Second, girls dominated as young starters in the elementary schools and had better scores in the languages section (Bahasa Indonesia and English). Meanwhile, boys tend to enroll at an older age, have better scores in Mathematics and gather more years of education. Lastly, participation in early childhood education significantly correlates with higher test scores in elementary school. It may be inferred that it is one aspect that increases the child's readiness to start schooling.

Moreover, the analysis shows that school starting age has a significant effect on academic performance too. Higher test scores in younger entrants might give an insight to parents and policymakers in order to decide the ideal age for children to start schooling. To support this idea, this study suggests that it is probable for the government of Indonesia to consider reducing the school starting age from seven years to six years. Therefore, by considering the advantages and disadvantages of an early entrance, the decision to start elementary school at a younger age could be a worthwhile investment.

To complement the policy of school entry age, it is crucial to strengthen the infrastructure of early childhood education and increase awareness regarding the importance of early childhood education. This is because early childhood education might be beneficial in providing children with fundamental academic skills, basic knowledge, and socialization strategies.

This study uses IFLS 5 to examine the effect of school starting age on the academic performance of students in elementary school. Even though the coverage of the IFLS survey carries a plethora of variables to support this study, the dataset may contain some missing information for each individual and can hence reduce the observations in the sample. However, to provide more statistical power, it would be better to combine the dataset with other waves. In addition to the scope of analysis, this study examines the short-term effects of school starting age on the elementary level. Future studies might use another level of 
schooling such as junior and senior high school to create a broader and richer analysis. Also, researchers could analyze the effect of school entrance age on earnings, entry into labor market, mental health, or the possibility of committing a crime for gauging the long-term effects.

\section{References}

Abdul Hakim. (2018). Pengaruh Usia Masuk Sekolah Dasar Terhadap Prestasi Belajar Sekolah dan Pesantren Siswa Kelas 2 Sekolah Dasar Pondok Al-Muqoddasah Ponorogo Jawa Timur.

Adri, Z. (2019). Usia Ideal Masuk SD Sebuah Pendekatan Psikologi. Gre Publishing.

Angrist, J. D., \& Krueger, A. B. (1992). The effect of age at school entry on educational attainment: An application of instrumental variables with moments from two samples. Journal of the American Statistical Association. https://doi.org/10.1080/01621459.1992.10475212

Becker, G. S. (1962). Investment in Human Capital: A Theoretical Analysis. Journal of Political Economy. https://doi.org/10.1086/258724

Bedard, K., \& Dhuey, E. (2006). The persistence of early childhood maturity: International evidence of long-run age effects. Quarterly Journal of Economics. https://doi.org/10.1162/qjec.121.4.1437

Black, S. E., Devereux, P. J., \& Salvanes, K. G. (2011). Too young to leave the nest? The effects of school starting age. Review of Economics and Statistics. https://doi.org/10.1162/REST_a_00081

Borghans, L., \& Diris, R. (2012). An Economic Analysis of the Optimal School Starting Age. SSRN Electronic Journal. https://doi.org/10.2139/ssrn.2022360

Cook, P. J., \& Kang, S. (2016). Birthdays, schooling, and crime: Regression-discontinuity analysis of school performance, delinquency, dropout, and crime initiation. American Economic Journal: Applied Economics, 8(1), 33-57. https://doi.org/10.1257/app.20140323

Cunha, F., Heckman, J. J., Lochner, L., \& Masterov, D. V. (2006). Chapter 12 Interpreting the Evidence on Life Cycle Skill Formation. Handbook of the Economics of Education, 1(06), 697-812. https://doi.org/10.1016/S1574-0692(06)01012-9

Datar, A. (2006). Does delaying kindergarten entrance give children a head start? Economics of Education Review. https://doi.org/10.1016/j.econedurev.2004.10.004

Dee, T. S., \& Sievertsen, H. H. (2018). The gift of time? School starting age and mental health. Health Economics (United Kingdom). https://doi.org/10.1002/hec.3638

Deliviana, E. (2017). Mempersiapkan Anak Masuk Sekolah Dasar. Jdp.

Dhuey, E., Figlio, D., Karbownik, K., \& Roth, J. (2019). School Starting Age and Cognitive Development. Journal of Policy Analysis and Management, 38(3), 538-578. https://doi.org/10.1002/pam.22135

Elder, T. E., \& Lubotsky, D. H. (2009). Kindergarten entrance age and children's achievement: Impacts of state policies, family background, peers. Journal of Human Resources, 44(3), 641-683. https://doi.org/10.3368/jhr.44.3.641

Fertig, M., \& Kluve, J. (2005). The Effect of Age at School Entry on Educational Attainment in Germany. IZA Discussion Paper. 
Fredriksson, P., \& Öckert, B. (2005). Is Early Learning Really More Productive? The Effect of School Starting Age on School and Labor Market Performance. IZA Discussion Paper, 1659.

Frölich, M., \& Huber, M. (2017). Including Covariates in the Regression Discontinuity Design. 11138.

Herbst, M., \& Strawiński, P. (2016). Early effects of an early start: Evidence from lowering the school starting age in Poland. Journal of Policy Modeling. https://doi.org/10.1016/j.jpolmod.2016.01.004

Kaila, M. (2017). The Effects of Relative School Starting Age on Educational Outcomes in Finland. VATT Institute for Economic Research.

Kartal, H., Balantekin, Y., \& Bilgin, A. (2016). The Importance of Early Childhood Education and School Starting Age in the Reading-Writing Learning Process. Participatory Educational Research, 3(1), 79-101. https://doi.org/10.17275/per.16.05.3.1

Kawaguchi, D. (2006). The Effect of Age at School Entry on Education and Income 1. Social Research, 162.

Kawaguchi, D. (2011). Actual age at school entry, educational outcomes, and earnings. Journal of the Japanese and International Economies. https://doi.org/10.1016/j.jjie.2009.02.002

Landersø, R., Nielsen, H. S., \& Simonsen, M. (2017). School Starting Age and the Crime-age Profile. Economic Journal. https://doi.org/10.1111/ecoj.12325

Lee, D. S., \& Lemieux, T. (2010). Regression Discontinuity designs in economics. Journal of Economic Literature. https://doi.org/10.1257/jel.48.2.281

Mayer, S. E. and D. K. (1999). "Does the Timing of School Affect How Much Children Learn?” In Earning and Learning: How School Matters (pp. 79-102). Brookings Institution and Russell Sage Foundation.

McEwan, P. J., \& Shapiro, J. S. (2008). The benefits of delayed primary school enrollment: Discontinuity estimates using exact birth dates. Journal of Human Resources. https://doi.org/10.3368/jhr.43.1.1

Pellizzari, M., \& Billari, F. C. (2012). The younger, the better? Age-related differences in academic performance at university. Journal of Population Economics, 25(2), 697-739. https://doi.org/10.1007/s00148-011-0379-3

Rizally, M. A. (2014). Korelasi antara usia kronologis awal masuk sekolah terhadap prestasi belajar. E-JUPEKhu (Jurnal Ilmiah Pendidikan Khusus), 3(September), 140-148.

Sharp, C. (2002). School Starting Age : European Policy and Recent Research. LGA Seminar "When Should Our Children Start School?"

Smith, J. (2009). Can regression discontinuity help answer an age-old question in education? the effect of age on elementary and secondary school achievement. B.E. Journal of Economic Analysis and Policy, 9(1). https://doi.org/10.2202/1935-1682.222 1

Stipek, D. (2002). At What Age Should Children Enter Kindergarten? A Question for Policy Makers and Parents. Social Policy Report. https://doi.org/10.1002/j.23793988.2002.tboo018.x

Strauss, J., Witoelar, F., \& Sikoki, B. (2016). The Fifth Wave of the Indonesia Family Life Survey: Overview and Field Report: Volume 1. In The Fifth Wave of the Indonesia Family Life Survey: Overview and Field Report: Volume 1. https://doi.org/10.7249/wr1143.1 


\section{Fawina Aulia Guswandi}

Wicaksono, T. Y., \& Witoelar, F. (2019). Early Experience and Later Outcomes of Education: Schooling Transition Evidence from Indonesia. Bulletin of Indonesian Economic Studies, 55(1), 29-60. https://doi.org/10.1080/00074918.2018.1439156

Zhang, S., Zhong, R., \& Zhang, J. (2017). School starting age and academic achievement: Evidence from China's junior high schools. China Economic Review, 44(2016), 343354. https://doi.org/10.1016/j.chieco.2017.03.004 